\title{
Phytochemistry, Food Application, and Therapeutic Potential of the Medicinal Plant (Withania coagulans): A Review
}

\author{
Muhammad Issa Khan ${ }^{1, *}{ }^{\circ}$, Maria Maqsood ${ }^{1}$, Raakia Anam Saeed ${ }^{1}$, Amna Alam ${ }^{1}$, Amna Sahar ${ }^{1,2}$, \\ Marek Kieliszek ${ }^{3}$ (D), Antoni Miecznikowski ${ }^{4}$, Hafiz Shehzad Muzammil ${ }^{1}$ and Rana Muhammad Aadil ${ }^{1, *(D)}$ \\ 1 National Institute of Food Science and Technology, University of Agriculture, Faisalabad 38000, Pakistan; \\ mariamaqsood75@gmail.com (M.M.); raakia.anam@gmail.com (R.A.S.); amnahnd17@gmail.com (A.A.); \\ amnasahar@uaf.edu.pk (A.S.); shehzad.muzammil@uaf.edu.pk (H.S.M.) \\ 2 Department of Food Engineering, University of Agriculture, Faisalabad 38000, Pakistan \\ 3 Department of Food Biotechnology and Microbiology, Institute of Food Sciences, Warsaw University of Life \\ Sciences-SGGW, Nowoursynowska 159 C, 02-776 Warsaw, Poland; marek_kieliszek@sggw.edu.pl \\ 4 Department of Fermentation Technology, Prof. Waclaw Dabrowski Institute of Agricultural and Food \\ Biotechnology—State Research Institute, Rakowiecka 36, 02-532 Warsaw, Poland; \\ antoni.miecznikowski@ibprs.pl \\ * Correspondence: drkhan@uaf.edu.pk (M.I.K.); muhammad.aadil@uaf.edu.pk (R.M.A.)
}

check for updates

Citation: Khan, M.I.; Maqsood, M.; Saeed, R.A.; Alam, A.; Sahar, A.; Kieliszek, M.; Miecznikowski, A.; Muzammil, H.S.; Aadil, R.M. Phytochemistry, Food Application, and Therapeutic Potential of the Medicinal Plant (Withania coagulans): A Review. Molecules 2021, 26, 6881. https://doi.org/10.3390/ molecules26226881

Academic Editors: Nunziatina De Tommasi, Giuliana Donadio and Ammar Bader

Received: 27 September 2021 Accepted: 14 November 2021 Published: 15 November 2021

Publisher's Note: MDPI stays neutral with regard to jurisdictional claims in published maps and institutional affiliations.

Copyright: (c) 2021 by the authors. Licensee MDPI, Basel, Switzerland. This article is an open access article distributed under the terms and conditions of the Creative Commons Attribution (CC BY) license (https:// creativecommons.org/licenses/by/ $4.0 /)$.

\begin{abstract}
Herbal plants have been utilized to treat and cure various health-related problems since ancient times. The use of Ayurvedic medicine is very significant because of its least reported side effects and host of advantages. Withania coagulans (Family; Solanaceae), a valuable medicinal plant, has been used to cure abnormal cell growth, wasting disorders, neural as well as physical problems, diabetes mellitus, insomnia, acute and chronic hepatic ailments. This review provides critical insight regarding the phytochemistry, biological activities, and pharmacognostic properties of $W$. coagulans. It has been known to possess diuretic, anti-inflammatory, anti-bacterial, anti-fungal, cardio-protective, hepato-protective, hypoglycemic, anti-oxidative, and anti-mutagenic properties owing to the existence of withanolides, an active compound present in it. Apart from withanolides, $W$. coagulans also contains many phytochemicals such as flavonoids, tannins, and $\beta$-sterols. Several studies indicate that various parts of $W$. coagulans and their active constituents have numerous pharmacological and therapeutic properties and thus can be considered as a new drug therapy against multiple diseases.
\end{abstract}

Keywords: Ayurvedic properties; diuretic; phytochemistry; pharmacognostic properties

\section{Introduction}

Plants are potential sources of medicinal compounds and have been used as ancient healing systems since antiquity. Some medicinal plants are enriched with diverse bioactive constituents. These bioactive constituents have been reported as beneficial to prevent and treat various disorders for maintaining a healthy life. One of the most important medicinal plants of genus Withania is Withania coagulans in the Ayurvedic medicinal system owing to its effective nutraceutical as well as pharmaceutical attributes. It is grown in various regions of the world such as in the Mediterranean region and from North Africa to South Asia [1]. Among twenty-three identified species of genus Withania, only two (W. coagulans and W. somnifera) have economic significance [2]. This plant is widely used to coagulate milk due to the presence of an enzyme in its berries, which is commonly known as an Indian cheesemaker [3]. Figure 1 depicts the leaves, stems, and fruit of the W. coagulans plant. The fruit, roots, and leaves have various therapeutic effects. The main constituents in berries include essential oils, esterases, amino acids, and alkaloids [4]. The healing properties of the plant are attributed to steroid derivative compounds "Withanolides". There are several withanolides such as coagulin F, coagulanolide, withacoagulin, and 
coagulin G present in the whole plant [3]. The ripe fruit of the plant is sweet and used for wound healing, asthma and dyspepsia, and as a sedative. In many countries, dry fruit is also used as a traditional treatment for diabetes [5] and as an antibacterial [6], antimicrobial [7], hepatoprotective [8], hypolipidemic [9], antioxidant [10], anti-tumor [11], antidepressant [12], immunosuppressive [13], and anti-inflammatory agent [14]. Seeds are useful for reducing inflammation, as a diuretic, and also in curing ophthalmia, while flower buds showed anthelmintic activity [15-17]. Twigs of the plant are used for cleaning teeth, as toothache and blood purifier agents in South Asian regions [3]. By considering the growing utilization of medicinal plants and their application in various indigenous health systems, this review is intended to provide comprehensive knowledge on phytochemistry, food uses, and the therapeutic potential of $W$. coagulans.

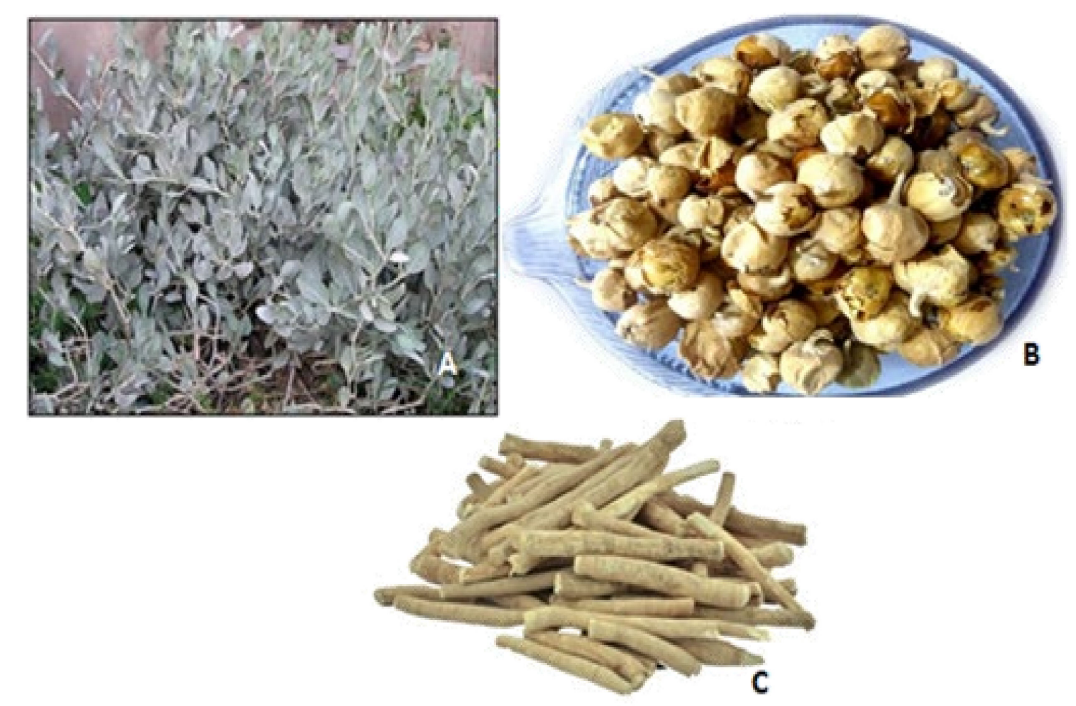

Figure 1. W. coagulans plant. (A): Leaves, (B): Fruits, (C): Stems.

\section{Nutritional Profile}

W. coagulans is a renowned herb due to its ethnopharmacological properties. It has been utilized as a herbal remedy and is widely distributed in Iran, Pakistan, Afghanistan, and East India. W. coagulans is a good source of macro and micronutrients. The mineral composition of $W$. coagulans is summarized in Table 1. It contains a small fraction of moisture, protein, fat, and fiber and is also a good source of carbohydrates. Studies also indicate a higher amount of magnesium (greater than Alhagi maurorum, Berberis lyceum, and Tecomella undulate), calcium (greater than Dature alba, A. maurorum, Chenopodium album, B. lyceum, T. undulate), potassium (greater than B. lyceum and T. undulate), and iron (greater than D. alba, B. lyceum, and T. undulata) in W. coagulans [4]. Roots are composed of ash $(1.92 \%)$, carbohydrates $(75.71 \%)$, lipids $(5.5 \%)$, protein $(2.95 \%)$, and fiber $(5.76 \%)$. Leaves are composed of ash $(3.26 \%)$, carbohydrates $(65.31 \%)$, lipids $(5 \%)$, protein $(2.95 \%)$, and fiber $(11.76 \%)$. Moreover, fruit contains ash $(4.21 \%)$, carbohydrates $(60.14 \%)$, lipids $(5 \%)$, and protein (4.65\%) [18].

The berries of the $W$. coagulans are composed of milk coagulating enzymes, two esterase, free amino acids, and essential oil. Proline, tyrosine, valine, hydroxyproline, glycine, cysteine, asparagine, glutamic, and aspartic acids are the main amino acids that are present in the plant. Major fatty acids include arachidonic acid, stearic acid, palmitic acid, linoleic and oleic acids [3]. Furthermore, $n$-octatriacont-17-enoic acid, geranilan-10-olyl dihydrocinnamoate (aromatic ester), and geranilan-8-oic acid-10-olyl salicyloxy-2-O- $\beta$-D-glucofuranosyl-( $\left(6^{\prime \prime} \rightarrow 1^{\prime \prime \prime}\right)$ $O-\beta$-D-glucofuranosyl- $6^{\prime \prime \prime}-n$-octadec- $9^{\prime \prime \prime \prime}, 11^{\prime \prime \prime \prime \prime \prime \prime}$-dienoate(monoterpenic benzyl glucoside) in consort with two already identified fatty acids named as $n$-dotriacont-21-enoic acid and $n$-tetratriacontanoic acid were characterized in berries [19]. Similarly, research also detected twenty constituents in the essential oil of the $W$. coagulans fruit including sesquiterpenes (54\%) 
and esters $(21.50 \%)$ as dominant compounds followed by the presence of fatty acids (5.5\%) such as nonanoic acid, hexanoic acid, methyl ester of hexadecanoic acid, methyl ester of nondecanoic acid, methyl esters of 8,11-octadecadienoic acid, methyl ester of 9-octadecenoic acid, and ethyl ester of linoleic acid, alkanes $(9.11 \%)$, and the aldehydes $(0.32 \%)$ in smaller percentage [20]. The un-saponifiable matter of the plant seed is composed of triacontane as well as $\beta$-sitosterol and dihydrostigmasterol [21]. In addition, it was reported that seeds are composed of approximately $12-14 \%$ of oil. The presence of free sugar $(17.8 \%)$ in the form of D-galactose and $\mathrm{D}$-arabinose (1:1) in a de-fatted meal of the $W$. coagulans seeds was also elucidated with maltose present in trace amounts [22]. Higher percentages of $\beta$-sitosterol, as well as linoleic acid, were also found and reported for the hypo-cholesterolemic effect of corn oil in combination with $W$. coagulans $[15,23]$.

Table 1. Mineral composition of W. coagulans [4].

\begin{tabular}{ll}
\hline & Minerals $\mathbf{( m g / k g )}$ \\
\hline Macro-Minerals & \\
\hline Calcium & 9260 \\
Magnesium & 35,280 \\
Potassium & 2450 \\
Sodium & 125 \\
Micro-Minerals & \\
\hline Iron & 98.8 \\
Copper & 2.2 \\
Zinc & 40.2 \\
Chromium & 0.6 \\
Cadmium & 1.4 \\
Lead & 1.9 \\
Nickel & 1.8 \\
\hline
\end{tabular}

\section{Phytochemistry}

Withania species have been studied extensively by several researchers that subsequently led to the identification, characterization, and isolation of bioactive compounds in different parts of a plant. It includes several steroidal lactones, tannins, flavonoids, and alkaloids [24-26]. Ten new phytoconstituents were identified from air-dried W. coagulans fruit extracted with methanol and their structures were based on their chemical and spectral data [27]. Various constituents of $W$. coagulans were estimated in three different extracts namely, methanolic, hydroalcoholic, and chloroform. It was reported that total phenolic content $(55.9 \mathrm{mg} / \mathrm{g})$, total tannins $(76.6 \mathrm{mg} / \mathrm{g})$, total flavonoids $(0.88 \mathrm{mg} / \mathrm{g})$, and total flavanol $(0.25 \mathrm{mg} / \mathrm{g})$ were higher in the methanolic extract as compared to hydroalcoholic and chloroformic [28].

In a study conducted in Iran, the presence of flavonoids (5.70-6.50\%), anthocyanins (4.51-9.51 $\mu \mathrm{mol} / \mathrm{g})$, and total phenolics (14.91-23.7 $\mu \mathrm{g}$ gallic acid equivalent (GEA)/mg D.W) were confirmed in W. coagulans [29]. The leaves of $W$. coagulans demonstrated the levels of total phenolics (58.21 mg GEA/g) and flavonoids (47 mg rutin equivalent (RE)/g), respectively [30]. The important chemical constituents of this medicinal plant are the withanolides, a series of polyhydroxy steroidal lactones, mainly present in the leaves as well as roots. They are composed of C-28 steroidal lactones based on the ergostane structure and the six or five-membered lactone ring is formed by oxidation of C-22 and C-26 [25]. Their concentrations vary from $0.001 \%$ to $0.5 \%$ of the dry weight [26,31-33]. Two major groups include withanolides containing the modified carbocyclic structure and withanolides containing the unmodified skeleton (including the regular $\beta$-oriented side chains and the unusual $\alpha$-oriented side chains). They are classified into seven groups based on being derivatives of ergostane and include $5 \beta, 6 \beta$-epoxides; $6 \alpha, 7 \alpha$-epoxides; 5 -enes; intermediate compounds; $5 \alpha, 6 \alpha$-epoxides; $6 \beta, 7 \beta$-epoxides, and phenolic withanolides [31,34]. 
So far, several withanolides, alkaloids, and sitoindosides (withanolide with glucose molecule at carbon 27) have been reported and isolated from Withania species [24,26,35-46]. One of the most salient features that withanolide-producing plants possess is to host an oxygen function in almost all positions of side chains or carbocyclic skeletons. Novel structural variants arise by modifications in either the side chain or in the carbocyclic skeleton [15].

\section{Novel Isolated Compounds of W. coagulans}

Several compounds have been identified in different parts of $W$. coagulans including certain coagulans, coagulanolide, and coagulins. Choudhary et al., [40] identified 17 $\beta$ hydroxywithanolide K: [(20S,22R) $14 \alpha, 17 \beta, 20 \beta$-trihydroxy-1-oxo-witha-2,5,24-trienolide] and $17 \beta, 20 \beta$-dihydroxy-1-oxo-witha-2,5,24-trienolide in whole plant. Similarly, Shahwar [47] found withahejarin, withasomniferine-A along with coagulin A. Furthermore, identification and isolation of thirteen coagulins (Coagulin F, G, H, I, J, K, L, M, N, O, $\mathrm{P}, \mathrm{Q}$, and R) from the whole plant was reported $[41,48,49]$. W. coagulans also contains coagulin $U$ along with other metabolites such as methyl-4-benzoate and phytosterols $(\beta$ sitosterol, $\beta$-sitosterol glycoside). Similarly (22R),20 $\beta$-hydroxy-1-oxowitha-2,5,24-trienolide and (22R)-14,20-epoxy-17 $\beta$-hydroxy-1-oxowitha-3,5,25-trienolide which are also important constituents of it [50]. Moreover, 17 $\beta, 27$-dihydroxy-14,20-epoxy-1-oxo-22R-witha-3,5,24trienolide and $17 \beta$-hydroxy-14 $\alpha, 20 \alpha$-epoxy-1-oxo-(22R)-witha-3,5,24-trienolide were discovered [41]. Coagulin $S$ was also isolated, and its structure was elucidated by using spectroscopic techniques [44]. Coagulansin B and coagulanolide are also amongst the metabolites of $W$. coagulans [51,52]. Withacoagulin J was identified as well as isolated along with already known withanolide $H$ [53]. Withanolide named as $(20 R, 22 R)-14 \alpha, 17,20 \beta, 27-$ trihydroxy-1-oxowitha-5,24-dienolide-27 $\beta-(O-\beta$-D-glucopyranoside was also discovered latterly $[53,54]$. Furthermore, withacogulanoside-B along with five known withanolides was isolated [55]. The compounds present in different plant parts are given in Table 2. Furthermore, the structures of some withanolides are presented in Figure 2.

Table 2. Important constituents of roots, aerial parts, leaves, and fruits of W. coagulans.

\begin{tabular}{|c|c|c|}
\hline Molecules & Part of Plant & References \\
\hline Withaferin A & Root & [35] \\
\hline $\begin{array}{c}\text { (20R,22R)-6 } \alpha, 7 \alpha \text {-epoxy- } 5 \alpha, 20 \text {-dihydroxy-1-oxo-witha-2,24-dienolide) } \\
\text { (20S,22R)-6 } 6,7 \alpha \text {-epoxy-5 } \alpha \text {-hydroxy-1-oxo-witha-2,24-dienolide) } \\
\text { Withacoagin: }(20 R, 22 R)-5 \alpha, 20 \text {-dihydroxy-1-oxowitha-2,6,24-trienolide) }\end{array}$ & Root & [39] \\
\hline Coagulin B, Coagulin C, Coagulin D, Coagulin E, Coagulin R & $\begin{array}{c}\text { Aerial parts (leaves and stem), } \\
\text { whole plant }\end{array}$ & {$[48,52]$} \\
\hline Amyrin & Aerial parts (leaves and stem) & [50] \\
\hline $\begin{array}{c}\text { Withacoagulin A: } \\
\left(\frac{1}{4}(20 S, 22 R)-17 \beta, 20 \beta \text {-dihydroxy-1-oxowitha-3,5,14,24-tetraenolide }\right) \\
\text { Withacoagulin B: } \\
\left(\frac{1}{4}(20 R, 22 R)-20 \beta, 27-\text { dihydroxy-1-oxowitha-3,5,14,24-tetraenolide }\right) \\
\text { Withacoagulin C: } \\
\left(\frac{1}{4}(20 S, 22 R)-14 \alpha, 15 \alpha, 17 \beta, 20 \beta \text {-tetrahydroxy-1-oxowitha-3,5,24-trienolide }\right) \\
\text { Withacoagulin D: } \\
\left(\frac{1}{4}(20 S, 22 R)-14 \alpha, 17 \beta, 20 \beta, 27 \text {-tetrahydroxy-1-oxowitha-3,5,24-trienolide }\right) \\
\text { Withacoagulin E: } \\
\left(\frac{1}{4}(20 R, 22 R)-14 \beta, 20 \beta \text {-dihydroxy-1-oxowitha-2,5,24-trienolide }\right) \\
\text { Withacoagulin F: } \\
\left(\frac{1}{4}(20 R, 22 R)-14 \beta, 20 \beta \text {-dihydroxy-1-oxowitha-3,5,24-trienolide }\right) \\
\text { Withanolide L } \\
(22 R)-14 \alpha, 15 \alpha, 17 \beta, 20 \beta \text {-tetrahydroxy-1-oxowitha-2,5,24-trien-26,22-olide) }\end{array}$ & Aerial parts (leaves and stem) & [56] \\
\hline
\end{tabular}


Table 2. Cont.

\begin{tabular}{|c|c|c|}
\hline Molecules & Part of Plant & References \\
\hline $\begin{array}{c}\text { Coagulansin A: } \\
(14 \alpha, 17 S, 20 S, 22 R)-14,17,20,27 \text {-tetrahydroxy-1-oxowitha-2,5,24-trienolide) } \\
\text { Coagulansin B: }(3 \beta, 14 \alpha, 20 S, 22 R)-3,14,20 \text {-trihydroxy-1-oxowith-5-enolide) } \\
\text { Withanolide P: } \\
(1 / 4(17 \alpha, 22 R)-14,17,22 \text {-trihydroxy-1-oxoergosta-2,5,24-trien-26-oic acid } \\
\delta \text {-lactone })(14 R, 15 R, 17 S, 20 S, 22 R)-14,15,17,20 \text {-tetrahydroxy-1-oxowitha- } \\
2,5,24 \text {-trienolide) } \\
(14 R, 15 R, 17 S, 20 S, 22 R)-14,15,17,20 \text {-tetrahydroxy-1-oxowitha-3,5,24-trienolide) } \\
(14 S, 17 R, 20 S, 22 R)-14,17,20-\text {-trihydroxy-1-oxowitha-2,5,24-trienolide) } \\
(14 S, 17 R, 20 S, 22 R)-14,17,20 \text {-trihydroxy-1-oxowitha-3,5,24-trienolide) }\end{array}$ & Whole plant, aerial parts & {$[52,57]$} \\
\hline$(5,20 \alpha(R)$-dihydroxy- $6 \alpha, 7 \alpha$-epoxy-1-oxo-( $5 \alpha)$ witha-2,24-dienolide) & Aerial part (leaves) & [36] \\
\hline 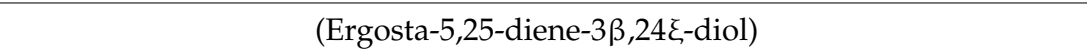 & Fruit & [38] \\
\hline $\begin{array}{l}\text { (3ß-hydroxy-2,3-dihydrowithanolide F) } \\
\text { Withanolide D }\end{array}$ & Fruit & [37] \\
\hline 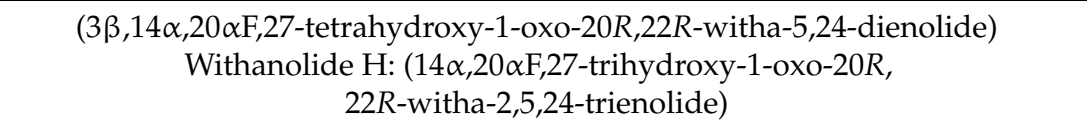 & Fruit & [58] \\
\hline Ajugin E & Fruit & [49] \\
\hline \multirow{2}{*}{ 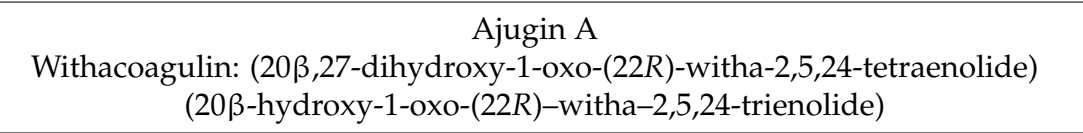 } & Fruit & [50] \\
\hline & Fruit & [43] \\
\hline $\begin{array}{c}\text { Coagulanolide } \\
(17 S, 20 S, 22 R)-14 \alpha, 15 \alpha, 17 \beta, 20 \beta \text {-tetrahydroxy-1-oxowitha-2,5,24-trienolide) }\end{array}$ & Fruit & [51] \\
\hline$(20 R, 22 R)-14,20 \alpha, 27$-trihydroxy-1-oxowitha-3,5,24-trienolide & Fruit & [56] \\
\hline
\end{tabular}

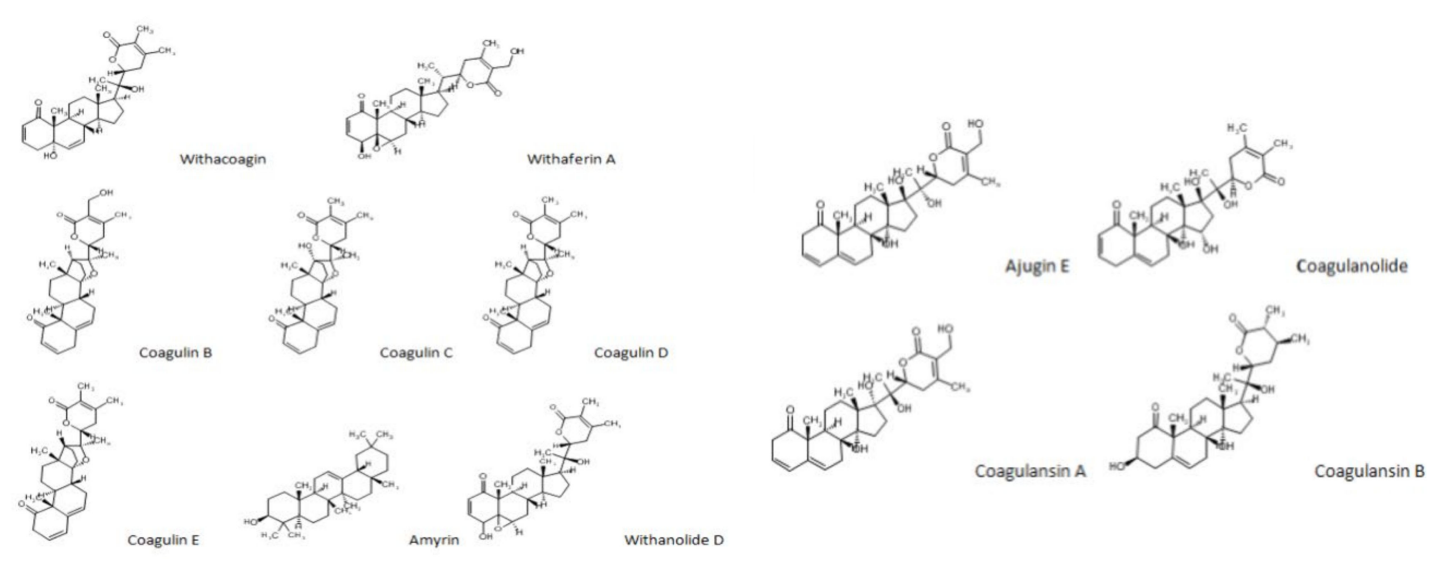

Figure 2. Structure of Withanolides of W. Coagulans.

\section{Application in the Food Industry}

Berries of $W$. coagulans are well known for their milk coagulating potential. Keeping this property in view, the milk coagulating activity of protease from the plant was assessed. A temperature of $70^{\circ} \mathrm{C}$ and $\mathrm{pH} 4$ were found to be optimal for enzymatic activity. However, $60^{\circ} \mathrm{C}$ was a stable temperature for the activity of the enzyme; SDS-PAGE showed a $66 \mathrm{kDa}$ band [59]. Furthermore, the fruit extract of $W$. coagulans was utilized to assess the milk coagulating potential which demonstrated the highest impact at $\mathrm{pH}$ of 4 and temperature of $65^{\circ} \mathrm{C}$. Additionally, the time for rennet congealing of the extract was observed to be in direct relation with concentrations of $\mathrm{NaCl}$ or inversely with enzyme concentrations (protease inhibitors). Moreover, pepstatin-A (aspartic-protease inhibitor) completely inhibited the enzymatic potential of the berry extract [60]. 
An enzyme aspartic protease was isolated by using fractional ammonium-sulfate precipitation and cation-exchange chromatography from $W$. coagulans fruit. Furthermore, SDS-PAGE revealed the existence of a monomeric protein with a molecular weight of $31 \mathrm{kDa}$. The proteolytic activity of the protease enzyme was assessed using casein revealed $\mathrm{K}_{\mathrm{m}}(1.29 \mathrm{mg} / \mathrm{mL})$ and $\mathrm{V}_{\max }(0.035 \mu \mathrm{mol} \mathrm{Tyr} / \mathrm{min})$ values for the protease enzyme. Skim milk was utilized to assess the milk coagulating potential of $W$. coagulans crude fruit extract. Consequently, mass spectrometry and inhibition assays revealed that aspartic protease is the only enzyme involved in milk coagulation. Additionally, the increasing salts concentrations $\left(\mathrm{NaCl}, \mathrm{CaCl}_{2}\right)$ gradually reduced the enzyme activity. Thus, it was concluded that this enzyme may be apt to produce the low salt cheese [61]. The protease was extracted from the berries of the plant and used for the production of white cheese. It was documented that cheese from $W$. coagulans was more acidic than cheeses prepared from other rennet sources [62].

Buffalo milk mozzarella cheese was developed by using fruits of $W$. coagulans as milk coagulants. Thus, an aqueous fraction of $W$. coagulans may be a suitable option for cheese production [63]. Buffalo milk cheese was developed by using an extract of the fruit of $W$. coagulans and was evaluated in terms of storage conditions ( 5 months). The highest content of ash, fat, crude protein as well as total solids was observed in cheese prepared with lyophilized berry extract [64]. Cheese preparation was done by using alcoholic and aqueous fractions of $W$. coagulans at different levels $(0.5,1$, and $1.5 \%)$ containing plant proteinase [65].

Furthermore, the preparation of cottage cheese from an aqueous fraction of plant showed significantly higher moisture content as well as $\mathrm{pH}$, however, no difference in ash, fat, and crude protein was observed in cheese prepared from calf rennet and $W$. coagulans [66]. An acceptable quality white cheese can be developed by the utilization of $0.5 \%$ alcoholic extract of the plant. The soy milk coagulating potential of $W$. coagulans extract was assessed in tofu preparation and compared with calcium-sulfate tofu. Sensory analysis revealed no difference between both types of tofu. However, yield as well as moisture content was lower in W. coagulans's tofu [67].

\section{Application in Nanotechnology}

Silver nanoparticles (AgNPs) have prodigious potential on behalf of their mechanistic role in biomedical research. Approaches involving green chemistry have gained copious attention recently in plant science for the production of nanoparticles. Keeping in view this fact, leaf extract $W$. coagulans was utilized for the development of reduced graphene oxide (RGO) $/ \mathrm{Fe}_{3} \mathrm{O}_{4}$ based nanocomposite with palladium nanoparticles ( $\left.\mathrm{Pd} / \mathrm{RGO} / \mathrm{Fe}_{3} \mathrm{O}_{4}\right)$ and resulted in the reduction in 4-nitrophenol in the water at ambient temperature [68]. Silver nanoparticles were developed by using $W$. coagulans leaf extract and characterization of those nanoparticles was conducted by using UV-Vis, scanning electron microscopy, energy dispersive X-ray analysis, transmission electron microscopy, X-ray powder diffraction, and Fourier transform infra-red. The cumulative result indicated the size of particles as $14 \mathrm{~nm}$ having a spherical face-centered cubic structure [69].

Encapsulation of the water extract was performed by developing chitosan nanoparticles coated with food-based starch to retard extract release in the stomach. The release was retarded by 2.5 times by this method, hence exerting hypoglycemic potential [70]. W. coagulans was utilized to develop iron oxide nanorods. Iron oxide nanorods with an average size of $16 \pm 2 \mathrm{~nm}$ and highly crystalline nature was obtained [6]. Furthermore, Keshari [71] also used $W$. coagulans extract to develop green silver nanoparticles. Those nanoparticles were crystalline, elemental, and spherical which also showed anti-biotic potential.

\section{Therapeutic Potential of W. coagulans}

A number of medicinal properties are attributed to $W$. coagulans such as antifungal, anti-cytotoxic, antidiabetic, hypolipidemic, neuroprotective, anti-inflammatory, anticancerous, anthelmintic, antioxidant activity, and wound healing activity [15]. Various 
pharmacological and therapeutic activities of $W$. coagulans are attributed to the various plant parts including roots, leaves, and fruits as shown in Figure 3. The anti-inflammatory mechanism of action of cogulin L isolated from W. coagulans is illustrated in Figure 4. Available literature indicates the therapeutic role of $W$. coagulans and its withanolides is summarized in Table 3.

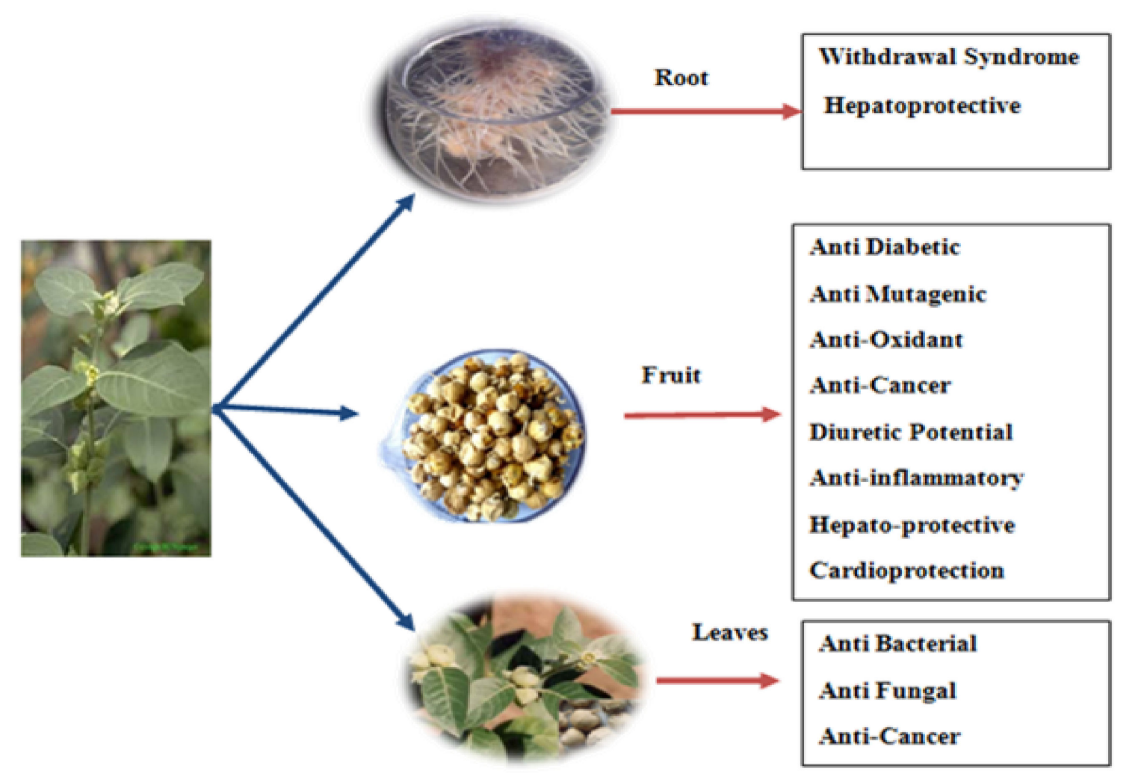

Figure 3. Graphical representation of the therapeutic potential of W. coagulans in several ailments.

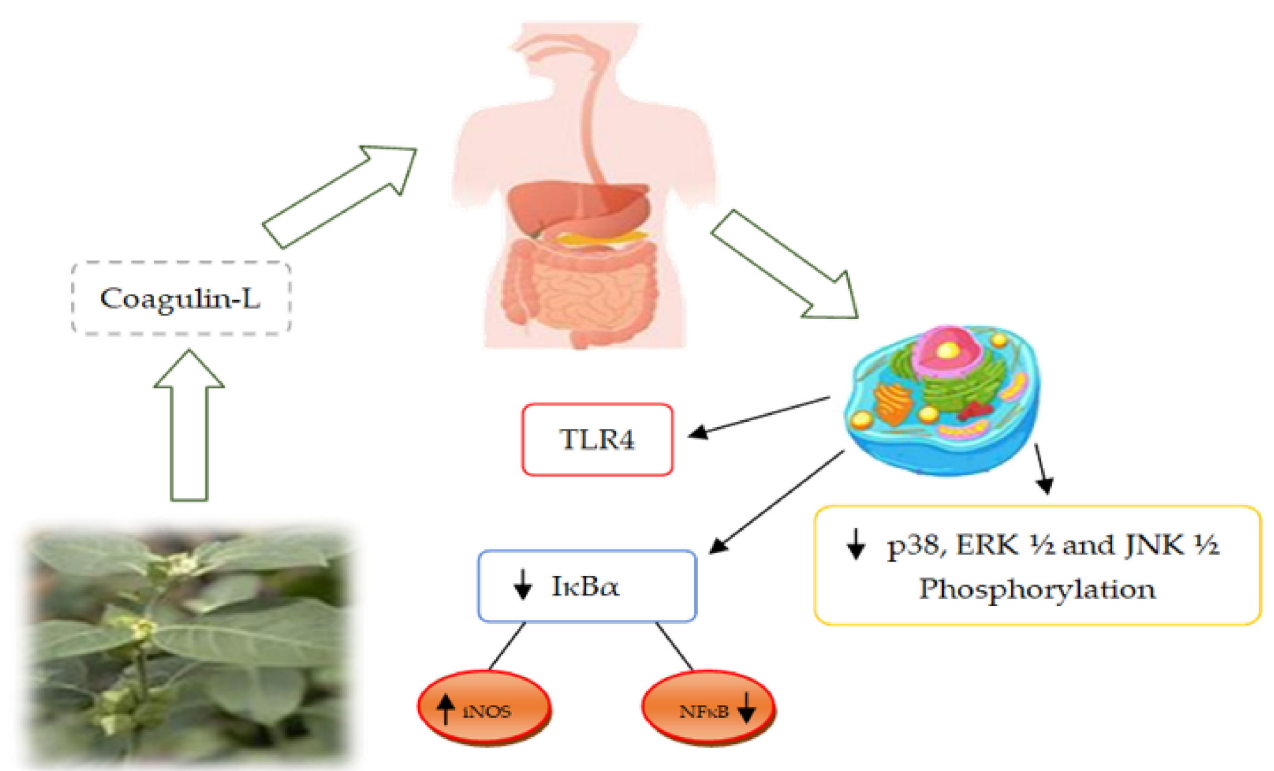

Figure 4. Anti-inflammatory potential of $W$. coagulans $(\mathrm{I} \kappa \mathrm{B} \alpha$ : Nuclear factor of kappa light polypeptide gene, iNOS: Inducible NO synthase, NFKB: Nuclear factor of kappa light polypeptide gene, TLR4: Toll-like receptor 4, ERK1/2: Extracellular signal regulator kinase, JNK1/2: c-Jun-N-terminal kinase. 
Table 3. Therapeutic potential of $W$. coagulans.

\begin{tabular}{|c|c|c|c|c|c|}
\hline $\begin{array}{l}\text { Part of } \\
\text { Plant }\end{array}$ & Type of Intervention & Experimental Model & Dosage & Outcomes & References \\
\hline \multicolumn{6}{|c|}{ Cardioprotective Potential } \\
\hline Fruit & Methanolic extract & $\begin{array}{c}\text { Rabbits } \\
(1-1.5 \mathrm{~kg} \text { weight })\end{array}$ & $\begin{array}{l}200 \text { and } \\
600 \mathrm{mg} / \mathrm{kg} \mathrm{BW}\end{array}$ & $\begin{array}{l}\text { Improved lipid profile, HMG-COA } \\
\text { reductase, lipase, and } \\
\text { antioxidant activities }\end{array}$ & [9] \\
\hline Fruit & $\begin{array}{l}\text { Withacoagulin and } \\
\text { coagulin } C\end{array}$ & $\begin{array}{l}\text { Female Albino rats } \\
\quad(100-120 \mathrm{~g})\end{array}$ & $\begin{array}{l}25 \text { and } \\
50 \mathrm{mg} / \mathrm{kg} \\
\mathrm{BW}\end{array}$ & $\begin{array}{l}\text { Antihypertensive impact in a } \\
\text { dose-dependent manner }\end{array}$ & [72] \\
\hline Fruit & Withacoagulin & $\begin{array}{l}\text { Male Albino rats } \\
\quad(120-150 \mathrm{~g})\end{array}$ & $25 \mathrm{mg} / \mathrm{kg} \mathrm{BW}$ & $\begin{array}{l}\text { Superoxide dismutase, catalase, } \\
\text { creatinine phosphokinase, and lactate } \\
\text { dehydrogenase significantly reduced }\end{array}$ & [73] \\
\hline \multicolumn{6}{|c|}{ Hepatoprotective Activity } \\
\hline Fruit & $\begin{array}{l}\text { Methanolic and } \\
\text { aqueous-methanolic } \\
\text { extracts }(80 \%)\end{array}$ & $\begin{array}{l}\text { Albino rats } \\
(170-220 \mathrm{~g})\end{array}$ & $800 \mathrm{mg} / \mathrm{kg} \mathrm{BW}$ & $\begin{array}{l}\text { An improvement as well as } \\
\text { biosynthesis of liver and bile duct } \\
\text { specific enzymes. Maintenance of the } \\
\text { integrity of the hepatic membrane }\end{array}$ & [8] \\
\hline \multicolumn{6}{|c|}{ Anti-inflammatory and Immune Modulatory Activity } \\
\hline Fruit & Coagulin L & $\begin{array}{l}\text { Human murine cells, } \\
\text { mice model } \\
\text { (male Swiss } \\
\text { Albino mice) }\end{array}$ & $\begin{array}{c}1,3,10 \mu \mathrm{M} \text { (In vitro) } \\
10,25, \text { and } \\
50 \mathrm{mg} / \mathrm{kg} \mathrm{BW}\end{array}$ & $\begin{array}{l}\text { Suppression of TLR4 induced } \\
\text { immune-mediators including } \\
\text { cytokines, growth factors, nitric and } \\
\text { superoxide led towards } \\
\text { immune-modulatory responses. } \\
\text { Moreover, it reduced the degradation } \\
\text { of } \mathrm{I} \mathrm{B} \alpha \text { which in turn inhibited the } \\
\text { expression of NF- } \mathrm{k} B \text { by } \\
\text { downregulating the expression of } \\
\text { iNOS and release of } \\
\text { pro-inflammatory cytokines }\end{array}$ & [14] \\
\hline Fruit & $\begin{array}{l}\text { Ethanolic extract } \\
\qquad(50 \%)\end{array}$ & $\begin{array}{l}\text { Broiler chicken } \\
\quad(550 \text { male) }\end{array}$ & $\begin{array}{c}0,75, \text { and } \\
150 \mathrm{mg} / \mathrm{kg} \text { diet }\end{array}$ & $\begin{array}{c}\text { The concentration of immunoglobulin } \\
\mathrm{G} \text { was significantly improved through } \\
\text { improving humoral response at the } \\
\text { dosage of } 150 \mathrm{mg} / \mathrm{kg} \text { diet }\end{array}$ & [13] \\
\hline $\begin{array}{l}\text { Aerial } \\
\text { parts }\end{array}$ & $\begin{array}{c}\text { Crude extract } \\
\text { (methanol and } \\
\text { chloroform in } 1: 1 \text { ) }\end{array}$ & $\begin{array}{l}\text { Sprague Dawley rats } \\
\qquad(180-220 \mathrm{~g})\end{array}$ & $\begin{array}{l}200,100 \text { and } \\
50 \mathrm{mg} / \mathrm{kg} \text { BW }\end{array}$ & Anti-inflammatory impact (70.0\%) & [74] \\
\hline Plant & $\begin{array}{c}\text { Methanolic extract } \\
(80 \%)\end{array}$ & $\begin{array}{l}\text { Wistar rats } \\
(150-200 \mathrm{~g})\end{array}$ & $\begin{array}{c}250 \text { and } \\
500 \mathrm{mg} / \mathrm{kg} \mathrm{BW}\end{array}$ & $\begin{array}{l}\text { Anti-inflammatory and } \\
\text { antioxidant activity }\end{array}$ & [75] \\
\hline Fruit & Aqueous extract & In vitro analysis & - & $\begin{array}{l}\text { Strong antioxidant and free radical } \\
\text { scavenging potential }\end{array}$ & {$[10]$} \\
\hline \multicolumn{6}{|c|}{ Antibacterial, Antifungal and Diuretic Activity } \\
\hline $\begin{array}{l}\text { Roots and } \\
\text { leaves }\end{array}$ & $\begin{array}{l}\text { Chloroform, ethyl } \\
\text { acetate, and } \\
\text { aqueous extract }\end{array}$ & $\begin{array}{l}\text { Bacterial strains } \\
\text { (Gram-positive and } \\
\text { Gram-negative) }\end{array}$ & $\begin{array}{l}0.5,1,1.5, \text { and } \\
2 \mathrm{mg} / \mathrm{mL}\end{array}$ & $\begin{array}{l}\text { Chloroform leaves and ethyl acetate } \\
\text { stem extracts at a dose of } 2 \mathrm{mg} / \mathrm{mL} \\
\text { had significant inhibition activity } \\
\text { against bacterial pathogens as } \\
\text { compared to aqueous extract }\end{array}$ & [76] \\
\hline Fruit & Methanolic extract & $\begin{array}{l}\text { Klebsiella pneumonia, } \\
\text { Escherichia coli, } \\
\text { Salmonella paratyphi, } \\
\text { Staphylococcus aureus, } \\
\text { Bacillus subtilis, and } \\
\text { Micrococcus luteus }\end{array}$ & $20 \mu \mathrm{g} / \mathrm{mL}$ & $\begin{array}{l}\text { The highest inhibition by the } \\
\text { methanolic extract was reported } \\
\text { against Bacillus subtilis at } 12 \mathrm{~mm}\end{array}$ & [7] \\
\hline Fruit & Methanolic extract & $\begin{array}{l}\text { Male Charles Foster } \\
\text { Albino rats } \\
(150-200 \mathrm{~g})\end{array}$ & $400 \mathrm{mg} / \mathrm{kg}$ BW & $\begin{array}{l}\text { The nephron-protective role was } \\
\text { illustrated by the reduction in levels } \\
\text { of free radical, renal function test, and } \\
\text { protection from DNA damage }\end{array}$ & [77] \\
\hline Leaves & $\begin{array}{l}\text { Silver nanoparticles } \\
\quad \text { (leaf extract) }\end{array}$ & $\begin{array}{l}\text { Bacterial strains } \\
\text { (Gram-positive and } \\
\text { Gram-negative) }\end{array}$ & $\begin{array}{l}5,10,15, \text { and } \\
20 \mu \mathrm{g} / \mathrm{mL}\end{array}$ & $\begin{array}{l}\text { It curbed the growth of both } \\
\text { gram-positive and negative bacteria }\end{array}$ & [69] \\
\hline
\end{tabular}


Table 3. Cont.

\begin{tabular}{|c|c|c|c|c|c|}
\hline $\begin{array}{l}\text { Part of } \\
\text { Plant }\end{array}$ & Type of Intervention & Experimental Model & Dosage & Outcomes & References \\
\hline Fruits & $\begin{array}{l}\text { Silver nanoparticles } \\
\quad \text { (fruit extract) }\end{array}$ & $\begin{array}{l}\text { Enterococcus faecalis, } \\
\text { Staphylococcus aureus, } \\
\text { Escherichia coli, } \\
\text { Proteus vulgaris, } \\
\text { Salmonella typhi, and } \\
\text { Vibrio cholera }\end{array}$ & $50 \mu \mathrm{g} / \mathrm{mL}$ & $\begin{array}{c}\text { Phenolic constituents present in the } W \text {. } \\
\text { coagulans can reduce silver nitrate into } \\
\text { the silver nanoparticles. Moreover, } \\
\text { bactericidal and bacteriostatic activity } \\
\text { was elucidated }\end{array}$ & {$[71]$} \\
\hline Fruit & $\begin{array}{l}\text { Iron oxide nanorods } \\
\text { (biological and } \\
\text { chemical) }\end{array}$ & $\begin{array}{c}\text { Pseudomonas } \\
\text { aeuroginosa and } \\
\text { Staphylococcus aureus }\end{array}$ & 5,10, and $20 \mu \mathrm{g} / \mathrm{mL}$ & $\begin{array}{c}\text { The study indicated that biological } \\
\text { nanorods are more effective (30\% } \\
\text { higher activity) than chemically } \\
\text { prepared nanorods. W. coagulans } \\
\text { nanoparticles showed significant } \\
\text { inhibitory potential against } P \text {. } \\
\text { aeuroginosa and } S \text {. aureus that indicates } \\
\text { these nanoparticles are more effective } \\
\text { than chemically } \\
\text { prepared nanoparticles }\end{array}$ & {$[6]$} \\
\hline Fruit & Aqueous extract & $\begin{array}{c}\text { In vitro } \\
\text { (silver carp fillet) }\end{array}$ & $\begin{array}{l}0.5 \% \text { extract, } 1 \% \\
\text { extract, } 1 \% \text { chitosan, } \\
1 \% \text { chitosan with } \\
0.5 \% \text { extract and } 1 \% \\
\text { chitosan with } \\
1 \% \text { extract }\end{array}$ & $\begin{array}{l}\text { Chitosan coating of extract } \\
\text { demonstrated debility in levels of total } \\
\text { bacterial counts and psychrophilic } \\
\text { total bacterial counts as well as } \\
\text { enhanced shelf life of fish fillets }\end{array}$ & {$[78]$} \\
\hline \multicolumn{6}{|c|}{ Hypoglycemic Potential } \\
\hline $\begin{array}{l}\text { Whole } \\
\text { plant }\end{array}$ & $\begin{array}{c}n \text {-butanol and } \\
\text { chloroform extract }\end{array}$ & In vitro and in silico & $\begin{array}{c}\text { Ajugin } \mathrm{E} \\
(66.7 \pm 3.6 \mu \mathrm{M}) \\
\text { withaperuvin } \mathrm{C} \\
(407 \pm 4.5 \mu \mathrm{M}) \\
\text { withanolid } \mathrm{J} \\
(683 \pm 0.94 \mu \mathrm{M})\end{array}$ & $\begin{array}{l}\text { Withacogulanoside-B from } n \text {-butanol } \\
\text { fraction and withaperuvin } C \text { as well } \\
\text { as } 27-\text { hydroxywithanolide I with } \\
\text { another } 3 \text { known withanolides } \\
\text { (chloroform fraction) were identified. } \\
\text { Among these, ajugin E showed higher } \\
\alpha \text {-glucosidase inhibition potential }\end{array}$ & {$[55]$} \\
\hline Fruit & Ethanolic extract & $\begin{array}{l}\text { Wistar rats and } \\
\text { in vitro }\end{array}$ & $400 \mathrm{mg} / \mathrm{kg}$ BW & $\begin{array}{c}\text { W. coagulans suppressed the DPP-4 } \\
\text { levels }(63.2 \%) \text { in an in vitro model at } \\
14 \mu \mathrm{g} / \mathrm{mL} \text {. Furthermore, restoration of } \\
\text { pancreatic-endocrinal tissues was } \\
\text { observed }\end{array}$ & {$[5]$} \\
\hline $\begin{array}{l}\text { Whole } \\
\text { plant }\end{array}$ & Aqueous extract & Sprague Dawley rats & $100 \mathrm{mg} / \mathrm{kg} \mathrm{BW}$ & $\begin{array}{l}\text { W. coagulans showed a promising } \\
\text { impact on postprandial insulin level } \\
\text { and amended the architecture of beta } \\
\text { cells of the pancreas }\end{array}$ & {$[79]$} \\
\hline $\begin{array}{l}\text { Whole } \\
\text { plant }\end{array}$ & Aqueous extract & $\begin{array}{l}\text { Male Sprague } \\
\text { Dawley rats } \\
(200-300 \mathrm{~g})\end{array}$ & $1000 \mathrm{mg} / \mathrm{kg} \mathrm{BW}$ & $\begin{array}{l}\text { W. coagulans improved expression of } \\
\text { glucagon-like peptide } 1 \text { which in turn } \\
\text { reduced fasting as well as } \\
\text { postprandial glucose levels }\end{array}$ & {$[80]$} \\
\hline Fruit & Aqueous extract & $\begin{array}{l}\text { In vitro (mice } \\
\text { pancreatic } \beta \text {-cells) } \\
\text { In vivo (Male ICR } \\
\text { mice; } 28-36 \mathrm{~g})\end{array}$ & $\begin{array}{l}\text { In vitro }(1,2,5,10, \\
\text { and } 25 \mu \mathrm{M}) \\
\text { In vivo } \\
(50 \mathrm{mg} / \mathrm{kg} \mathrm{BW})\end{array}$ & $\begin{array}{l}\text { Secretions of insulin were promoted } \\
\text { 2-fold in cells treated with the extract. } \\
\text { Furthermore, in vivo testing } \\
\text { corroborated to suppress the levels of } \\
\text { blood glucose by } 60 \%\end{array}$ & {$[70]$} \\
\hline Fruit & Aqueous extract & In vitro & $0-100 \mu \mathrm{g} / \mathrm{mL}$ & $\begin{array}{l}\text { Chromatographic analysis revealed } \\
\text { the presence of } \\
17 \beta \text {-hydroxywithanolide K, } \\
\text { withanolide F, and coagulin C in fruit } \\
\text { fraction that was further illustrated } \\
\text { cytotoxic potential against HepG2 } \\
\text { cells. Both EAF and WF promoted } \\
\text { insulin secretions and inhibition of } \\
\text { glucose absorption }\end{array}$ & [81] \\
\hline
\end{tabular}


Table 3. Cont.

\begin{tabular}{|c|c|c|c|c|c|}
\hline $\begin{array}{l}\text { Part of } \\
\text { Plant }\end{array}$ & Type of Intervention & Experimental Model & Dosage & Outcomes & References \\
\hline Bud & Chloroform extract & $\begin{array}{l}\text { In vitro } \\
\text { (L6 rat skeletal } \\
\text { muscle cells) }\end{array}$ & $\begin{array}{l}3.906,7.8125,15.62,5 \\
31.25,62.5,125,250 \\
\text { and } 500 \mu \mathrm{g} / \mathrm{mL}\end{array}$ & $\begin{array}{l}\text { W. coagulans bud illustrated significant } \\
\text { uptake of glucose via GLUT- } 4 \text { and } \\
\text { activity of PPAR gamma that resulted } \\
\text { in enhanced glucose dumping and } \\
\text { insulin sensitivity in skeletal muscles }\end{array}$ & [82] \\
\hline \multicolumn{6}{|c|}{ Anticancer Activity } \\
\hline $\begin{array}{l}\text { Whole } \\
\text { plant }\end{array}$ & $\begin{array}{c}\text { Hydro-methanolic } \\
\text { extract }\end{array}$ & $\begin{array}{l}\text { Forty male Wistar } \\
\text { rats }(200-250 \mathrm{~g})\end{array}$ & $1000 \mathrm{mg} / \mathrm{kg} \mathrm{BW}$ & $\begin{array}{c}\text { W. coagulans extract treatment } \\
\text { induced cell apoptosis in the prostate } \\
\text { and the expression of } \\
\text { cyclooxygenase- } 2 \text { in the prostatic } \\
\text { tissues were effectively reduced }\end{array}$ & [83] \\
\hline Fruit & Methanolic extract & $\begin{array}{l}\text { Human breast cancer } \\
\text { and normal kidney } \\
\text { epithelial cell lines }\end{array}$ & $20-200 \mu \mathrm{g} / \mathrm{mL}$ & $\begin{array}{l}\text { Methanolic fruit extract showed } \\
\text { substantial anticancer activity by } \\
\text { reducing cell viability }\end{array}$ & [11] \\
\hline Leaves & $\begin{array}{c}\text { Methanol and } \\
\text { chloroform extract }\end{array}$ & $\begin{array}{l}\text { Cell cultures include } \\
\text { normal and } \\
\text { cancerous human } \\
\text { prostate cell lines }\end{array}$ & $10-250 \mu \mathrm{g} / \mathrm{mL}$ & $\begin{array}{l}\text { Extract exerted its cancer-preventing } \\
\text { action by inducing apoptosis, } \\
\text { decreasing cell viability, invasion, cell } \\
\text { proliferation, and migration of } \\
\text { prostate cancerous cells }\end{array}$ & {$[84]$} \\
\hline $\begin{array}{l}\text { Whole } \\
\text { plant }\end{array}$ & $\begin{array}{c}\text { Water and methanol } \\
\text { extract }\end{array}$ & $\begin{array}{l}\text { Forty Wistar rats } \\
\quad(200-250 \mathrm{~g})\end{array}$ & $\begin{array}{c}250,500, \text { and } \\
1000 \mathrm{mg} / \mathrm{kg} \mathrm{BW}\end{array}$ & $\begin{array}{l}\text { W. coagulans extract caused decreased } \\
\text { malondialdehyde levels and increased } \\
\text { total antioxidant capacity levels in the } \\
\text { prostate gland }\end{array}$ & [85] \\
\hline Fruit & Ethanol extract & $\begin{array}{l}\text { Human breast cancer } \\
\text { cell line }\end{array}$ & $\begin{array}{l}0,10,20,40,80,160 \\
\text { and } 320 \mu \mathrm{g} / \mathrm{mL}\end{array}$ & $\begin{array}{c}\text { Plant extract arrested cell cycle at } \\
\mathrm{G}_{2} / \mathrm{M} \text { phase and was found } \\
\text { non-hemolytic }\end{array}$ & [86] \\
\hline $\begin{array}{l}\text { Root, leaf, } \\
\text { leaf stalk, } \\
\text { and fruit }\end{array}$ & Methanolic extracts & $\begin{array}{l}\text { Human and rat } \\
\text { cancer cell lines }\end{array}$ & $20 \mu \mathrm{g} / \mathrm{mL}$ & $\begin{array}{l}\text { The leaf stalk extract showed the } \\
\text { highest cytotoxic activity against all } \\
\text { tested cell lines }\end{array}$ & [87] \\
\hline Leaf & $\begin{array}{l}\text { Silver } \\
\text { nanoparticles(leaf } \\
\text { extract) }\end{array}$ & $\begin{array}{l}\text { Cervical cancerous } \\
\text { hyper-triploid } \\
\text { cell-lines }\end{array}$ & $0.25-30 \mathrm{mg} / \mathrm{L}$ & $\begin{array}{c}\text { Silver nanoparticles containing } \\
\text { withanolides unveiled cytotoxic and } \\
\text { apoptotic potential }\end{array}$ & [69] \\
\hline \multicolumn{6}{|c|}{ Other Health Benefits } \\
\hline $\begin{array}{l}\text { Whole } \\
\text { plant }\end{array}$ & $\begin{array}{c}\text { Hydroalcoholic } \\
\text { extract }\end{array}$ & Male Wistar rats (48) & $\begin{array}{c}250,500, \text { and } \\
1000 \mathrm{mg} / \mathrm{kg} \mathrm{BW} / \text { day }\end{array}$ & $\begin{array}{l}\text { Results showed a significant decrease } \\
\text { in sperm count, gonadosomatic index, } \\
\text { and sperm viability }\end{array}$ & [85] \\
\hline $\begin{array}{l}\text { Whole } \\
\text { plant }\end{array}$ & Ethanolic extracts & $\begin{array}{l}\text { Vermicidal activity } \\
\text { against } \\
\text { Pheretima posthuma } \\
\text { earthworm }\end{array}$ & 75 and $100 \mathrm{mg} / \mathrm{mL}$ & $\begin{array}{l}\text { W. coagulans extract exhibited } \\
\text { remarkable anti-helminthic activity } \\
\text { against } P \text {. posthuma }\end{array}$ & [17] \\
\hline Fruit & Alcoholic extract & Swiss Albino mice & $\begin{array}{c}200,500, \text { and } \\
1000 \mathrm{mg} / \mathrm{kg} \mathrm{BW}\end{array}$ & $\begin{array}{l}\text { Fruit extract was evaluated as an } \\
\text { antidepressant as it reduced the } \\
\text { immobility and increased the mobility } \\
\text { in rats through tail suspension test }\end{array}$ & [88] \\
\hline Root & $\begin{array}{c}\text { Ethanol water }(3: 1) \\
\text { extract }\end{array}$ & Male Wistar rats & $\begin{array}{c}500 \text { and } \\
1000 \mathrm{mg} / \mathrm{kg} \mathrm{BW}\end{array}$ & $\begin{array}{l}\text { Neuro-protective potential against } \\
\text { oxidative stress-induced injury was } \\
\text { illustrated with enhancement in the } \\
\text { number of intact neurons and } \\
\text { suppression in the number of TUNEL } \\
\text { neurons in the hippocampal region }\end{array}$ & [89] \\
\hline Roots & $\begin{array}{l}\text { Methanol and water } \\
\qquad(3: 1)\end{array}$ & $\begin{array}{l}\text { Male Wistar rats } \\
\quad(220-250 \mathrm{~g})\end{array}$ & $1000 \mathrm{mg} / \mathrm{kg} \mathrm{BW}$ & $\begin{array}{l}\text { Preischemic extract administration } \\
\text { effectively increased the antioxidant } \\
\text { status (catalase, glutathione } \\
\text { peroxidase, and superoxide dismutase } \\
\text { level) and reduced the } \\
\text { malondialdehyde level in the striatum } \\
\text { brain region. }\end{array}$ & [90] \\
\hline
\end{tabular}


Table 3. Cont.

\begin{tabular}{|c|c|c|c|c|c|}
\hline $\begin{array}{l}\text { Part of } \\
\text { Plant }\end{array}$ & Type of Intervention & Experimental Model & Dosage & Outcomes & References \\
\hline Roots & $\begin{array}{l}\text { Methanol and } \\
\text { water }(3: 1)\end{array}$ & $\begin{array}{l}\text { Male Wistar rats } \\
\quad(220-250 \mathrm{~g})\end{array}$ & $1000 \mathrm{mg} / \mathrm{kg} \mathrm{BW}$ & $\begin{array}{l}\text { Preischemic extract administration } \\
\text { effectively increased the antioxidant } \\
\text { status (catalase, glutathione } \\
\text { peroxidase, and superoxide dismutase } \\
\text { level) and reduced the } \\
\text { malondialdehyde level in the striatum } \\
\text { brain region. }\end{array}$ & [90] \\
\hline $\begin{array}{l}\text { Whole } \\
\text { plant }\end{array}$ & $\begin{array}{l}\text { Methanol and } \\
\text { chloroform (1:1). }\end{array}$ & $\begin{array}{l}\text { Sprague-Dawley rats } \\
\quad(180-220 \mathrm{~g})\end{array}$ & $\begin{array}{l}200,100, \text { and } \\
50 \mathrm{mg} / \mathrm{kg} \mathrm{BW}\end{array}$ & $\begin{array}{l}\text { The antinociceptive potential of } W \text {. } \\
\text { coagulans estimated via hot plate assay } \\
\text { elucidated pain reduction by } 65.3 \% \\
\text { and } 62 \% \text { by writhing assay }\end{array}$ & {$[74]$} \\
\hline Fruits & Methanolic extract & Mice & $\begin{array}{c}100 \text { and } \\
250 \mathrm{mg} / \mathrm{kg} \text { BW }\end{array}$ & $\begin{array}{c}\text { Study results suggested analgesic and } \\
\text { sedative activity of } W \text {. coagulans }\end{array}$ & [91] \\
\hline Fruit & Alcoholic extract & Swiss Albino mice & $\begin{array}{c}200 \mathrm{mg} / \mathrm{kg}, \\
500 \mathrm{mg} / \mathrm{kg}, \text { and } \\
1000 \mathrm{mg} / \mathrm{kg}\end{array}$ & $\begin{array}{l}\text { The alcoholic extract did not exhibit } \\
\text { an antidepressant effect in rats, but it } \\
\text { showed a depressive effect on mood }\end{array}$ & [92] \\
\hline Fruit & Alcoholic extract & Swiss Albino mice & $\begin{array}{c}200,500 \text { and } \\
1000 \mathrm{mg} / \mathrm{kg} \mathrm{BW}\end{array}$ & $\begin{array}{l}\text { Rota road test also exhibited central } \\
\text { nervous system depressant activity }\end{array}$ & [88] \\
\hline Fruit & Alcoholic extract & Swiss Albino mice & $\begin{array}{c}\text { 200, and } \\
1000 \mathrm{mg} / \mathrm{kg} \mathrm{BW}\end{array}$ & $\begin{array}{c}\text { Results showed no considerable } \\
\text { association between } W \text {. coagulans fruit } \\
\text { extract and catalepsy }\end{array}$ & [93] \\
\hline Fruit & $\begin{array}{l}\text { Hydroalcoholic } \\
\text { extract (50\% ethanol) }\end{array}$ & $\begin{array}{l}\text { Male one-day-old } \\
\text { broiler chickens }(600)\end{array}$ & $\begin{array}{c}0,100, \text { or } \\
200 \mathrm{mg} / \mathrm{kg} \text { diet }\end{array}$ & $\begin{array}{l}\text { Non-significant impact on the } \\
\text { mineralization of tibia bone was } \\
\text { illustrated. Dietary calcium level was } \\
\text { declined by } 30 \% \text { and total antibodies } \\
\text { level was not influenced significantly }\end{array}$ & {$[94,95]$} \\
\hline Fruit & $\begin{array}{l}\text { Hydroalcoholic } \\
\text { extract }\end{array}$ & $\begin{array}{l}\text { Male one-day-old } \\
\text { broiler chickens (550) }\end{array}$ & $\begin{array}{c}150 \text { and } \\
75 \mathrm{mg} / \mathrm{kg} \text { diet }\end{array}$ & $\begin{array}{l}\text { W. coagulans and } W \text {. somnifera } \\
\text { administration increased the } \\
\text { bone mineralization }\end{array}$ & [96] \\
\hline
\end{tabular}

\section{Conclusions}

W. coagulans possesses considerable therapeutic potential and has been employed as a remedy against various disorders and diseases due to the presence of withanolides. It also possesses esterases, free amino acids, fatty oils, and essential oils. Medicinal properties of W. coagulans such as hepatoprotective, anti-inflammatory, hypoglycaemic, cardioprotective, free radical scavenging, antimicrobial, central nervous system depressant, immunomodulation, antitumor, and cytotoxic activities have been revealed by several pharmacological studies. However, future studies are needed to explore the mechanisms of action of compounds isolated from $W$. coagulans in higher animals to confirm their protective activity and safety. Crude extracts from different parts of the plant especially from the fruit have significant medicinal potential. Modern medications can be developed after thorough research into the mechanism of action, bioactivity, toxicity, and pharmacotherapeutic potential of plant-derived beneficial chemicals, as well as clinical trials and standardization.

Author Contributions: All authors contributed equally for original drafting, editing and finalizing of the review paper. Conceptualization, M.I.K. and M.M.; draft preparation, M.I.K., M.M. and R.A.S.; tables and figures preparation, M.M., M.K., A.A., A.S. and H.S.M.; writing-review and editing, M.K., A.M. and R.M.A.; supervision, M.I.K. and R.M.A. All authors have read and agreed to the published version of the manuscript.

Funding: This research received no external funding.

Institutional Review Board Statement: Not applicable.

Informed Consent Statement: Not applicable.

Data Availability Statement: Not applicable. 
Conflicts of Interest: The authors declare no conflict of interest.

\section{References}

1. Pandey, I.; Nama, K.S. Withania coagulans (Stocks) Dunal A rare ethnomedicinal plant of the Western Rajasthan Desert. Int. J. Pharmaceut. Biomed. Res. 2015, 2, 34-40.

2. Negi, M.; Sabharwal, V.; Wilson, N.; Lakshmikumaran, M. Comparative analysis of the efficiency of SAMPL and AFLP in assessing genetic relationships among Withania somnifera genotypes. Curr. Sci. 2006, 91, 464-471.

3. Gupta, V.; Keshari, B.B. Withania coagulans Dunal (paneer doda): A review. Int. J. Ayurvedic Herb. Med. 2013,3 , $1130-1136$.

4. Ullah, Z.; Baloch, M.K.; Khader, J.A.; Baloch, I.B.; Ullah, R.; AbdEIslam, N.M.; Noor, S. Proximate and nutrient analysis of selected medicinal plants of Tank and South Waziristan area of Pakistan. Afr. J. Pharm. Pharmacol. 2013, 7, 179-184. [CrossRef]

5. Ram, H.; Kumar, P.; Purohit, A.; Kashyap, P.; Kumar, S.; Kumar, S.; Singh, G.; Alqarawi, A.A.; Hashem, A.; Abd_Allah, E.F. Improvements in HOMA indices and pancreatic endocrinal tissues in type-2 diabetic rats by DPP-4 inhibition and antioxidant potential of an ethanol fruit extract of Withania coagulans. Nutr. Metab. 2021, 18, 1-17. [CrossRef] [PubMed]

6. Qasim, S.; Zafar, A.; Saif, M.S.; Ali, Z.; Nazar, M.; Waqas, M.; Haq, A.U.; Tariq, T.; Hassan, S.G.; Iqbal, F. Green synthesis of iron oxide nanorods using Withania coagulans extract improved photocatalytic degradation and antimicrobial activity. J. Photochem. Photobiol. B Biol. 2020, 204, 111784. [CrossRef]

7. Peerzade, N.; Sayed, N.; Das, N. Antimicrobial and phytochemical screening of methanolic fruit extract of Withania coagulans L. Dunal for evaluating the antidiabetic activity. Pharma Innov. J. 2018, 7, 197-204.

8. Qureshi, S.A.; Jahan, M.; Lateef, T.; Ahmed, D.; Rais, S.; Azmi, M.B. Presence of gallic acid and rutin improve the hepatoprotective strength of Withania coagulans. Pak. J. Pharm. Sci. 2019, 32, 301-308.

9. Lateef, T.; Qureshi, S.A. Centratherum anthelminticum and Withania coagulans improves lipid profile and oxidative stress in triton X-100 induced hyperlipidemic rabbits. Group 2020, 1, 1-22.

10. Keshari, A.K.; Srivastava, A.; Upadhayaya, M.; Srivastava, R. Antioxidants and free radicals scavenging activity of medicinal Plants. J. Pharmacogn. Phytochem. 2018, 7, 1499-1504.

11. Ahmad, R.; Fatima, A.; Srivastava, A.; Khan, M.A. Evaluation of apoptotic activity of Withania coagulans methanolic extract against human breast cancer and vero cell lines. J. Ayurveda Integr. Med. 2017, 8, 177-183. [CrossRef] [PubMed]

12. Gosavi, D.D.; Kamdi, A.S.; Kalambe, S.M.; Bohra, P.N. The motor coordination activity of alcoholic extract of Withania coagulans fruits in Swiss albino mice by rota rod test. Indian J. Pharm. Pharmacol. 2020, 7, 73-76.

13. Mirakzehi, M.; Hosseini, S.; Saleh, H. The effects of hydroalcoholic extracts of Withania somnifera root, Withania coagulans fruit and 1, 25-dihydroxycholecalciferol on immune response and small intestinal morphology of broiler chickens. J. Appl. Anim. Res. 2017, 45, 591-597. [CrossRef]

14. Reddy, S.S.; Chauhan, P.; Maurya, P.; Saini, D.; Yadav, P.P.; Barthwal, M.K. Coagulin-L ameliorates TLR4 induced oxidative damage and immune response by regulating mitochondria and NOX-derived ROS. Toxicol. Appl. Pharmacol. 2016, 309, 87-100. [CrossRef] [PubMed]

15. Maurya, R.; Jayendra, A. Chemistry and pharmacology of Withania coagulans: An Ayurvedic remedy. J. Pharm. Pharmacol. 2010, 62, 153-160. [CrossRef]

16. Mudassir, H.A.; Nazim, K.; Khan, U.A.; Qureshi, S.A. Comparative evaluation of hypoglycemic activity, trace minerals and phytochemical contents of some potential medicinal plant extracts. Int. J. Biol. Biotechnol. 2018, 15, 55-62.

17. Saratha, R.; KAS, M.S.; Sundari, K.K. Evaluation of anti-helminthic activity of ethanolic extract of Withania coagulans. Res. J. Pharm. Sci. 2019, 8, 555X.

18. Hameed, I.; Hussain, F. Proximate and elemental analysis of five selected medicinal plants of family Solanaceae. Pak. J. Pharm. Sci. 2015, 28, 1203-1215.

19. Ali, A.; Jameel, M.; Ali, M. New fatty acid, aromatic ester and monoterpenic benzyl glucoside from the fruits of Withania coagulans Dunal. Nat. Prod. Res. 2015, 29, 1307-1314. [CrossRef]

20. Shahnaz, B.; Tahira, M.; Ismat, N. Chemical composition of the essential oil of Withania coagulans. Asian J. Chem. 2010, 22, 122-126.

21. Vishnoi, H.; Garg, A.K.; Meena, G.C.; Singh, C.; Sharma, L.N. Pharmacognostical and pharmacological evaluation of Withania coagulans-An important ethnomedicinal plant. World J. Pharm. Med. Res. 2017, 3, 106-111.

22. Salam, A.; Wahid, M. Free sugars and a galactoaraban from Withania coagulans seeds. Pak. J. Biochem. 1969, 2, 18-21.

23. Atal, C.; Sethi, P. A preliminary chemical examination of Withania coagulans. Indian J. Pharm. Sci. 1963, 25, 163-164.

24. Abbas, S.; Jamal, S.A.; Choudhary, M.I. New withanolides from Withania sp. J. Nat. Prod. 1993, 56, 1000-1006.

25. Kapoor, L. Handbook of Ayurvedic Medicinal Plants: Herbal Reference Library, 1st ed.; CRC Press: Boca Raton, FL, USA, 2000; Volume 2.

26. Jain, R.; Kachhwaha, S.; Kothari, S. Phytochemistry, pharmacology, and biotechnology of Withania somnifera and Withania coagulans: A review. J. Med. Plants Res. 2012, 6, 5388-5399.

27. Mir, S.R.; Ali, M.; Waris, M.; Sultana, S. Chemical constituents from the fruits of Withania coagulans (Stocks) Dunal. Trends Phytochem. Res. 2020, 4, 45-58.

28. Prasad, S.; Singh, P.; Wahi, A.; Hemalatha, S. Pharmacognostical standardization of Withania coagulans Dunal. Pharmacogn. J. 2010, 2, 386-394. [CrossRef] 
29. Valizadeh, M.; Bagheri, A.; Valizadeh, J.; Mirjalili, M.; Moshtaghi, N. Phytochemical investigation of Withania coagulans (Stocks) Dunal in natural habits of Sistan and Baluchestan province of Iran. Iran. J. Med. Aromat. Plants 2015, 31, $406-417$.

30. Azhar, M.F.; Naseer, U.; Aziz, A.; Zafar, S.; Qadir, I.; Farooq, M.; Ahmad, I.; Anjum, K. Antioxidant and phytochemical composition of leaves, stem and root extracts of Withania coagulans and Withania somnifera. Zeitschrift Arznei-Gewurzpflanzen 2020, 25, 27-30.

31. Glotter, E. Withanolides and related ergostane-type steroids. Nat. Prod. Rep. 1991, 8, 415-440. [CrossRef] [PubMed]

32. Alfonso, D.; Bernardinelli, G.; Kapetanidis, I. Withanolides from Iochroma coccineum. Phytochemistry 1993, 34, 517-521. [CrossRef]

33. Tursunova, R.; Maslennikova, V.; Abubakirov, N. Withanolides in the vegetable kingdom. Chem. Nat. Compd. 1977, 13, 131-138. [CrossRef]

34. Khodaei, M.; Jafari, M.; Noori, M. Remedial use of withanolides from Withania coagolans (Stocks) Dunal. Adv. Life Sci. 2012, 2, 6-19. [CrossRef]

35. Subramanian, S.S.; Sethi, P. Withaferin-A from the roots of Withania coagulans. Curr. Sci. 1969, 38, 267-268.

36. Subramanian, S.S.; Sethi, P.; Glotter, E.; Kirson, I.; Lavie, D. 5, $20 \alpha$ (R)-dihydroxy- $6 \alpha, 7 \alpha$-epoxy-1-oxo-( $5 \alpha)$ witha-2, 24-dienolide, a new steroidal lactone from Withania coagulans. Phytochemistry 1971, 10, 685-688. [CrossRef]

37. Budhiraja, R.; Sudhir, S.; Garg, K. Cardiovascular effects of a withanolide from Withania coagulans, Dunal fruits. Indian J. Physiol. Pharmacol. 1983, 27, 129-134. [PubMed]

38. Velde, V.V.; Lavie, D.; Budhiraja, R.D.; Sudhir, S.; Garg, K.N. Potential biogenetic precursors of withanolides from Withania coagulans. Phytochemistry 1983, 22, 2253-2257. [CrossRef]

39. Neogi, P.; Kawai, M.; Butsugan, Y.; Mori, Y.; Suzuki, M. Withacoagin, a new withanolide from Withania coagulans roots. Bull. Chem. Soc. Jpn. 1988, 61, 4479-4481. [CrossRef]

40. Choudhary, M.I.; Parveen, Z.; Jabbar, A.; Ali, I. Antifungal steroidal lactones from Withania coagulance. Phytochemistry 1995, 40, 1243-1246. [CrossRef]

41. Atta-ur-Rahman, A.; Choudhary, M.I.; Qureshi, S.; Gul, W.; Yousaf, M. Two new ergostane-type steroidal lactones from Withania coagulans. J. Nat. Prod. 1998, 61, 812-814. [CrossRef] [PubMed]

42. Shabbir, M.; Yousaf, M.; Qureshi, S.; Naz, A.; Choudhary, M.I. Three withanolides from Withania coagulans. Phytochemistry 1999, $52,1361-1364$.

43. Naz, A.; Choudhary, M.I. Withanolides from Withania coagulans. Phytochemistry 2003, 63, 387-390.

44. Nur-e-Alam, M.; Yousaf, M.; Qureshi, S.; Baig, I.; Nasim, S.; Choudhary, M.I. A novel dimeric podophyllotoxin-type lignan and a new withanolide from Withania coagulans. Helv. Chim. Acta 2003, 86, 607-614. [CrossRef]

45. Mirjalili, M.H.; Moyano, E.; Bonfill, M.; Cusido, R.M.; Palazón, J. Steroidal lactones from Withania somnifera, an ancient plant for novel medicine. Molecules 2009, 14, 2373-2393. [CrossRef] [PubMed]

46. Xu, Y.-M.; Gao, S.; Bunting, D.P.; Gunatilaka, A.L. Unusual withanolides from aeroponically grown Withania somnifera. Phytochemistry 2011, 72, 518-522. [CrossRef]

47. Shahwar, D.-E. Isolation and Structural Studies on the Withanolidal Constituents of Withania Coagulans; University of Karachi: Karachi, Pakistan, 1999.

48. Rahman, A.; Choudhary, M.I. New natural products from medicinal plants of Pakistan. Pure Appl. Chem. 1998, 70, 385-389. [CrossRef]

49. Nawaz, H.R.; Malik, A.; Khan, P.M.; Ahmed, S. Ajugin E and F: Two withanolides from Ajuga parviflora. Phytochemistry 1999, 52, 1357-1360. [CrossRef]

50. Naz, A. Studies on the Chemical Constituents of Withania coagulans and Boswellia dalzielli; University of Karachi: Karachi, Pakistan, 1999.

51. Maurya, R.; Singh, A.B.; Srivastava, A.K. Coagulanolide, a withanolide from Withania coagulans fruits and antihyperglycemic activity. Bioorganic Med. Chem. Lett. 2008, 18, 6534-6537. [CrossRef]

52. Jahan, E.; Perveen, S.; Fatima, I.; Malik, A. Coagulansins A and B, new withanolides from Withania coagulans Dunal. Helv. Chim. Acta 2010, 93, 530-535. [CrossRef]

53. Khan, S.A.; Adhikari, A.; Ayub, K.; Farooq, A.; Mahar, S.; Qureshi, M.N.; Rauf, A.; Khan, S.B.; Ludwig, R.; Mahmood, T. Isolation, characterization and DFT studies of epoxy ring containing new withanolides from Withania coagulans Dunal. Spectrochim. Acta Part A Mol. Biomol. Spectrosc. 2019, 217, 113-121. [CrossRef] [PubMed]

54. Khan, S.A.; Maher, S.; Naheed, N.; Mahmood, T.; Ayub, K.; Farooq, A.; Khan, S.B.; Shah, Z. Isolation, spectroscopic and density functional theory of two withanolide glycosides. J. Mol. Struct. 2019, 1177, 449-456. [CrossRef]

55. Maher, S.; Choudhary, M.I.; Saleem, F.; Rasheed, S.; Waheed, I.; Halim, S.A.; Azeem, M.; Abdullah, I.B.; Froeyen, M.; Mirza, M.U. Isolation of antidiabetic withanolides from Withania coagulans Dunal and their in vitro and in silico validation. Biology 2020, 9 , 197. [CrossRef]

56. Huang, C.F.; Ma, L.; Sun, L.J.; Ali, M.; Arfan, M.; Liu, J.W.; Hu, L.H. Immunosuppressive withanolides from Withania coagulans. Chem. Biodivers. 2009, 6, 1415-1426. [CrossRef] [PubMed]

57. Kuroyanagi, M.; Murata, M.; Nakane, T.; Shirota, O.; Sekita, S.; Fuchino, H.; Shinwari, Z.K. Leishmanicidal active withanolides from a Pakistani medicinal plant. Coagulans Chem. Pharm. Bull. 2012, 60, 892-897. [CrossRef]

58. Ramaiah, P.A.; Lavie, D.; Budhiraja, R.D.; Sudhir, S.; Garg, K.N. Spectroscopic studies on a withanolide from Withania coagulans. Phytochemistry 1984, 23, 143-149. [CrossRef] 
59. Beigomi, M.; Mohammadifar, M.A.; Hashemi, M.; Senthil, K.; Valizadeh, M. Biochemical and rheological characterization of a protease from fruits of Withania coagulans with a milk-clotting activity. Food Sci. Biotechnol. 2014, 23, 1805-1813. [CrossRef]

60. Kazemipour, N.; Salehi Inchebron, M.; Valizadeh, J.; Sepehrimanesh, M. Clotting characteristics of milk by Withania coagulans: Proteomic and biochemical study. Int. J. Food Prop. 2017, 20, 1290-1301. [CrossRef]

61. Salehi, M.; Aghamaali, M.R.; Sajedi, R.H.; Asghari, S.M.; Jorjani, E. Purification and characterization of a milk-clotting aspartic protease from Withania coagulans fruit. Int. J. Biol. Macromol. 2017, 98, 847-854. [CrossRef] [PubMed]

62. Pezeshki, A.; Hesari, J.; AHMADI, Z.A.; Ghambarzadeh, B. Influence of Withania coagulans protease as a vegetable rennet on proteolysis of Iranian UF white cheese. J. Agric. Sci. Technol. 2011, 13, 567-576.

63. Nawaz, M.A.; Masud, T.; Sammi, S. Quality evaluation of mozzarella cheese made from buffalo milk by using paneer booti (Withania coagulans) and calf rennet. Int. J. Dairy Technol. 2011, 64, 218-226. [CrossRef]

64. Qazalbash, M.A.; Masud, T.; Sammi, S.; Khan, R.S.; Latif, A. Effect of different storage conditions on coagulating properties and cheese quality of Withania coagulans extract. Int. J. Dairy Technol. 2018, 71, 654-662. [CrossRef]

65. Jooyandeh, H.; Ghasemi, A.; Hojjati, M.; Nasehi, B. Utilization of Withania coagulans extract as rennet replacer on color and physicochemical characteristics of ultrafilterated Iranian white cheese. Iran. J. Food Sci. Technol. 2020, 17, 1-13.

66. Khan, R.S.; Masud, T. Comparison of buffalo cottage cheese made from aqueous extract of Withania coagulans with commercial calf rennet. Int. J. Dairy Technol. 2013, 66, 396-401. [CrossRef]

67. Sarani, R.; Mohtadinia, J.; Asghari, J.M. The use of the Withania coagulans as a coagulant in the production of soya cheese and the effect of various additives on the sensory properties. J. Food Res. 2015, 25, 677-687.

68. Atarod, M.; Nasrollahzadeh, M.; Sajadi, S.M. Green synthesis of Pd/RGO/Fe3O4 nanocomposite using Withania coagulans leaf extract and its application as magnetically separable and reusable catalyst for the reduction of 4-nitrophenol. J. Colloid Interface Sci. 2016, 465, 249-258. [CrossRef]

69. Tripathi, D.; Modi, A.; Narayan, G.; Rai, S.P. Green and cost effective synthesis of silver nanoparticles from endangered medicinal plant Withania coagulans and their potential biomedical properties. Mater. Sci. Eng. C 2019, 100, 152-164. [CrossRef]

70. Sampathkumar, K.; Riyajan, S.; Tan, C.K.; Demokritou, P.; Chudapongse, N.; Loo, S.C.J. Small-intestine-specific delivery of antidiabetic extracts from Withania coagulans using polysaccharide-based enteric-coated nanoparticles. ACS Omega 2019, 4, 12049-12057. [CrossRef] [PubMed]

71. Keshari, A.; Srivastava, R.; Yadav, S.; Nath, G.; Gond, S. Synergistic activity of green silver nanoparticles with antibiotics. Nanomed. Res. J. 2020, 5, 44-54.

72. Quaisul, H. In vivo effect of withacoagulin and coagulin C isolated from Withania coagulans Dunal fruits on blood pressure of albino rats. World J. Adv. Res. Rev. 2019, 4, 27-32. [CrossRef]

73. Quaisul, H. In vivo cardioprotective effect of withacoagulin (20 $\beta, 27-D i h y d r o x y-1-o x o-(22 R)$-witha-2,5,24-tetraenolide) in experimental myocardial infarction in albino rats. World J. Adv. Res. Rev. 2020, 5, 36-42. [CrossRef]

74. Ismail, H.; Rasheed, A.; Haq, I.-U.; Jafri, L.; Ullah, N.; Dilshad, E.; Sajid, M.; Mirza, B. Five indigenous plants of Pakistan with antinociceptive, anti-inflammatory, antidepressant, and anticoagulant properties in Sprague Dawley rats. Evid.-Based Complementary Altern. Med. 2017, 2017, 7849501. [CrossRef]

75. Maher, S.; Shabbir, M.; Anam, I.; Khan, N.; Iqbal, S.; Saleem, F. Anti-inflammatory and anti-oxidant activities of methanolic extract of medicinal plants from Balochistan. Int. J. Biol. Biotechnol. 2020, 15, 691-697.

76. Ullah, A.; Khan, A. In vitro antibacterial potential of Withania coagulans Dunal (Solanaceae). J. Biodivers. Environ. Sci. 2018, 12, 139-146.

77. Sharma, S.; Joshi, A.; Hemalatha, S. Protective effect of Withania coagulans fruit extract on cisplatin-induced nephrotoxicity in rats. Pharmacogn. Res. 2017, 9, 354.

78. Sadeghi, M.; Arshadi, A.; Mirdar Harijani, J.M.H.; Haddadi, F. Antioxidant activity of chitosan edible coating enriched with aqueous extract of Withania coagulans fruit on chemical changes and sensory properties of silver carp (Hypophthalmichthys molitrix) stored in refrigerator. J. Fish. 2020, 72, 363-374.

79. Samad, A.; Sadiq, N.; Ayaz, H.; Rajpoot, N.N. Antidiabetic effect of withanolides and liraglutide on serum insulin level and pancreatic histology in diabetic rats. Prof. Med. J. 2019, 26, 1898-1903. [CrossRef]

80. Samad, A.; Rajpoot, N.N.; Ayaz, H.; Sadiq, N. Effect of Withania coagulans and liraglutide on serum Glp-1, postprandial and fasting blood glucose in streptozotocin induced diabetic rats. J. Bahria Univ. Med. Dent. Coll. 2019, 9, 120.

81. Siriporn, R. Evaluation of Antidiabetic Activity of the Water and Ethyl Acetate Fractions from Withania coagulans Fruits and the Mechanism Underlying Their Hypoglycemic Effects; School of Preclinic Institute of Science Suranaree University of Technology: Nakhon Ratchasima, Thailand, 2018.

82. Sandhiya, V.; Krishna, M.S. Effect of chloroform fraction of Withania coagulans bud on the regulation of GLUT4 and PPAR $\gamma$-expressions levels in diabetic L6 myotubes. Int. J. Life-Sci. Sci. Res. 2016, 2, 285-289. [CrossRef]

83. Sarbishegi, M.; Khajavi, O.; Arab, M.R. Withania coagulans extract induces cell apoptosis and inhibits COX-2 expression in a rat model of benign prostatic hyperplasia. Nephro-Urol. Mon. 2016, 8, e39284. [CrossRef]

84. Rehman, S.; Keefover-Ring, K.; ul Haq, I.; Dilshad, E.; Khan, M.I.; Akhtar, N.; Mirza, B. Drier climatic conditions increase withanolide content of Withania coagulans enhancing its inhibitory potential against human prostate cancer cells. Appl. Biochem. Biotechnol. 2019, 188, 460-480. [CrossRef] [PubMed] 
85. Sarbishegi, M.; Khajavi, O. Effects of hydro-alcoholic extract of Withania coagulans on antioxidant status and sperm parameters following testosterone administration in rat. J. Ilam Univ. Med. Sci. 2018, 26, 11-20. [CrossRef]

86. Gopinath, S.; Ismail Shareef, M.; Gupta, S.; Gupta, A. In vitro anticancer evaluation of Withania coagulans on breast cancer cell lines. World J. Pharm. Pharm. Sci. 2017, 6, 933-940.

87. Maqsood, M.; Qureshi, R.; Ikram, M.; Ahmad, M.S.; Jabeen, B.; Asi, M.R.; Khan, J.A.; Ali, S.; Lilge, L. In vitro anticancer activities of Withania coagulans against HeLa, MCF-7, RD, RG2, and INS-1 cancer cells and phytochemical analysis. Integr. Med. Res. 2018, 7, 184-191. [CrossRef] [PubMed]

88. Gosavi, D.D.; Kamdi, A.S. The antidepressant activity of alcoholic extract of Withania coagulans fruits in Swiss albino mice by tail suspension test. Natl. J. Physiol. Pharm. Pharmacol. 2020, 10, 527-529. [CrossRef]

89. Sarbishegi, M.; Heidari, Z.; Mahmoudzadeh-Sagheb, H.; Valizadeh, M.; Doostkami, M. Neuroprotective effects of Withania coagulans root extract on CA1 hippocampus following cerebral ischemia in rats. Avicenna J. Phytomed. 2016, 6, 399. [PubMed]

90. Mahmoudzadeh-Sagheb, H.; Heidari, Z.; Sarbishegi, M. Withania coagulans protects striatum from oxidative damages induced by global brain ischemia in rat. Jundishapur J. Nat. Pharm. Prod. 2018, 13, e65051. [CrossRef]

91. Ahmad, N.; Muhammad, S.; Fatima, K.; Ahmad, R.; Shahwani, N.A.; Jabbar, A. CNS depressant and analgesic effects of Withania coagulans (Stocks) Dunal fruits collected from Khuzdar district of Balochistan, Pakistan. Pure Appl. Biol. 2017, 6, 636-644. [CrossRef]

92. Kamdi, A.S.; Bohra, P.N.; Kalambe, S.M.; Chandrakapure, A.R. The antidepressant activity of the alcoholic extract of Withania coagulans fruits in Swiss albino mice by forced swimming test. Natl. J. Physiol. Pharm. Pharmacol. 2019, 9, 904-906. [CrossRef]

93. Kamdi, A.S.; Kokane, S.; Bohra, P.N.; Kalambe, S.M. The antipsychotic activity of alcoholic extract of Withania coagulans fruits in Swiss albino mice in haloperidol-induced catalepsy. Natl. J. Physiol. Pharm. Pharmacol. 2018, 8, 1654-1656. [CrossRef]

94. Hosseini, S.J.; Kermanshahi, H.; Nassirimoghaddam, H.; Nabipour, A.; Mirakzeh, M.T.; Saleh, H.; Kazemifard, M. Effects of 1.25-dihydroxycholecalciferol and hydroalcoholic extract of Withania coagulans fruit on bone mineralization and mechanical and histological properties of male broiler chickens. Braz. J. Poult. Sci. 2016, 18, 73-86. [CrossRef]

95. Hosseini, S.J.; Mirakzehi, M.; Saleh, H. The effects of dietary 1, 25-Dihydroxycholecalciferol (Calcitriol) and root hydroalcoholic extract of Withania coagulans on immune response and small intestinal morphology of broiler chickens. Sci.-Res. Iran. Vet. J. 2016, $12,27-32$.

96. Mirakzehi, M.; Hosseini, S.; Saleh, H. Effects of two plant extracts and vitamin D3 on bone mechanical and histological properties of broiler chickens. JAPS J. Anim. Plant Sci. 2018, 28, 686-694. 